\begin{tabular}{|c|c|c|}
\hline $\begin{array}{l}\text { OPEN ACCESS } \\
\text { Vol. } 4 \text { No. 2: } 42-46 \\
\text { Tahun 2021 } \\
\text { Artikel penelitian 圆 }\end{array}$ & $\begin{array}{l}\text { Eurmal Alsuditilestari } \\
\text { E-ISSN: 2598-8204 } \\
\text { http://ojs.umrah.ac.id/index.php/akuatiklestari } \\
\text { DOI: https://doi.org/10.31629/akuatiklestari.v4i2.3236 }\end{array}$ & $\frac{\vdots}{b=}$ \\
\hline
\end{tabular}

\title{
Pengaruh Sumber Air Berbeda dan Tanpa Perlakuan Terhadap Kelulushidupan Jangka Pendek Larva Litopanaeus vannamei
}

\author{
Effect of Different Sources Waters and Without Treatment on Short-Term Survival of Larvae \\ Litopenaeus vannamei
}

\section{Ela Juwita ${ }^{1}$, Neri Kautsari1 ${ }^{\bowtie}$, Frederich Bensianus L ${ }^{1}$, Andi Hayatuddin ${ }^{1}$}

1 Manajemen Sumberdaya Perairan, Fakultas Peternakan dan Perikanan, Universitas Samawa, Sumbawa Besar, NTB, Indonesia 84316

$\square$ Info Artikel:

Diterima: 22 April 2021

Revisi: 22 April 2021

Disetujui: 27 Mei 2021

Dipublikasi: 30 Mei 2021

\section{Keyword:}

Vannamei, salinitas, larva, kelulushidupan

\begin{abstract}
ABSTRAK. Udang vannamei merupakan jenis udang telah dibudiayakan di tambak dan bahkan di perairan darat (perairan tawar). Berbagai penelitian telah dilakukan terhadap keberlangsungan hidup udang vannamei terutama kaitannya dengan salinitas, namun belum ada informasi terkait kelulushidupan udang vannamei yang dipelihara pada berbagai sumber air. Penelitian ini bertujuan untuk mengetahui kelulushidupan larva udang vannamei post larva 12 yang dipelihara pada berbagai sumber air. Metode yang digunakan dalam penelitian ini adalah metode eksperimen. Pada penelitian ini terdapat tiga perlakuan yaitu pemeliharaan larva pada air yang bersumber dari laut, sumur dan dari muara. Masing-masing perlakuan terdapat tiga kali ulangan. Setiap wadah diisi dengan air media (sesuai perlakuan) sebanyak $2 \mathrm{~L}$. Larva dimasukkan ke dalam wadah setelah 15 menit dilakukan aklimatisasi. Jumlah larva pada setiap wadah adalah 50 individu ( 25 individu/L). Salinitas air laut adalah 19 ppt sedangkan salinitas air tawar dan air muara yang digunakan sebagai media pemeliharaan adalah 0 ppt. Pengamatan tingkat kematian dilakukan setiap 12 jam dan dilakukan selama 3 hari atau 72 jam. Hasil penelitian menunjukkan bahwa larva yang dipelihara di media air tawar mengalami kematian total (100\%) setelah $12 \mathrm{jam}$, sedangkan larva yang dipelihara pada media air muara mengalami kematian total $(100 \%)$ setelah 24 jam. Larva yang dipelihara di air laut tidak mengalami kematian hingga hari ke-tiga atau dapat dikatakan bahwa larva yang dipelihara di air laut memiliki tingkat kelulushidupan $100 \%$.
\end{abstract}

ABSTRACT. Vannamei shrimp is a species of shrimp that has been cultivated in ponds and even in land waters (freshwater). Various studies have been carried out on the survival of vannamei shrimp, especially in relation to salinity, but there is no information yet regarding the survival of vannamei shrimp that are reared in various water sources. This study aimed to determine the survival of post larva 12 vannamei shrimp larvae reared in various water sources. The method used in this research is the experimental method. In this study, there were three treatments, namely larval rearing in water sourced from the sea, wells and from the estuary. Each treatment had three replications. Each container was filled with media water (according to treatment) as much as $2 \mathrm{~L}$. The salinity of seawater is $19 \mathrm{ppt}$ while the salinity of freshwater and estuary water used as a maintenance medium is 0 ppt. Larva was put into the container after 15 minutes of acclimatization. The number of larvae in each container is 50 individuals ( 25 individuals / L). Observation of the mortality rate was carried out every 12 hours and carried out for 3 days or 72 hours. The results showed that larvae reared in freshwater media had total mortality $(100 \%)$ after 12 hours, while larvae reared in estuary water had total mortality $(100 \%)$ after 24 hours. Larvae reared in seawater do not die until the third day or it can be said that larvae reared in seawater have a $100 \%$ survival rate.

How to cite this article:

Juwita, E., Kautsari, N., Bensianus L, F., \& Hayatuddin, A.. (2021). Pengaruh Sumber Air Berbeda dan Tanpa Perlakuan Terhadap Kelulushidupan Jangka Pendek Larva Litopanaeus vannamei. Jurnal Akuatiklestari, 4(2): 42-46. DOI: https://doi.org/10.31629/akuatiklestari.v4i2.3236

\section{PENDAHULUAN}

Udang vannamei (Litopeneaus vannamei) merupakan udang introduksi yang secara ekonomis bernilai tinggi sebagai komoditi ekspor dan merupakan spesies penting dalam budidaya (Zhou et al., 2012). Hal ini dikarenakan udang vannamei merupakan udang yang diminati oleh pasar dunia. Baru-baru ini, L. vannamei yang diketahui bersifat eurihalin ini telah 
menjadi komoditas budidaya yang menjanjikan untuk budidaya di darat pada salinitas rendah. Roy et al., (2007) menyatakan bahwa akhir-akhir ini budidaya udang vannamei pada salinitas rendah menjadi budidaya populer di banyak negara. Budidaya udang salinitas rendah tidak hanya dapat mengendalikan wabah penyakit, tetapi juga memanfaatkan sepenuhnya tanah salin-alkali. Budidaya udang ini pada salinitas rendah didasari dari sifat udang vannamei yang bersifat eurihalin. Castille \& Lawrence (1981) menyatakan bahwa udang vannamei mampu mentoleransi salinitas dari 0,5 hingga 40 ppt. Saoud et al., (2003) menyatakan bahwa toleransi salinitas udang vannamei berkisar dari 0,5 sampai $50 \mathrm{mg} / 1$.

Salinitas adalah salah satu faktor lingkungan yang memengaruhi kehidupan udang vannamei. Variasi salinitas dapat merusak homeostasis dan menyebabkan stres yang signifikan, pertumbuhan yang lambat, tingkat kelangsungan hidup yang rendah yang pada akhirnya akan memengaruhi nilai ekonomi udang vannamei (Laramore et al., 2001; Li et al., 2007, Li et al., 2008). Beberapa penelitian telah melaporkan tentang dampak jangka panjang salinitas terhadap konsumsi oksigen (Lemos et al., 2001), perubahan histologis hepatopankreas (Li et al., 2008), kelangsungan hidup (Li et al., 2007) dan kinerja pertumbuhan (Ogle et al., 1992; Samocha et al., 1998; Silva et al., 2010).

Penelitian mengenai kelulushidupan udang vannamei pada berbagai salinitas peneliharaan telah banyak dilakukan. Gao et al., (2016) telah melakukan penelitian kelulushidupan larva pada salinitas 2, 10, 20 dan 30 ppt. Penelitian lainnya telah mengungkapkan kelulushidupan larva pada berbagai kondisi kualitas air, namun sebagian besar penelitian yang ada menggunakan air laut yang diencerkan sebagai media pemeliharaan. Pada umumnya, sebagian besar penelitian juga melakukan treatmen (perlakuan) terhadap air sebelum digunakan sebagai media pemeliharaan, padahal kondisi di lapangan (di masyarakat) umumnya tidak melakukan perlakuan khusus terhadap air yang digunakan. Informasi terkait kelulushidupan larva yang dibudidayakan di air tanpa melalui tahapan perlakuankhusus perlu dilakukan sebagai upaya untuk mengetahui kemampuan sumberdaya air sebagai media pemeliharaan. Informasi seperti ini juga dapat digunakan sebagai dasar dalam menentukan kualitas larva atau benur dari berbagai tempat pemebenihan udang vannamei.

Informasi penting lainnya yang perlu diketahui dalam pemeliharaan udang vannamei ialah tingkat kelulushidupan udang vannamei yang dipelihara pada berbagai sumber air. Selama ini, informasi terkait kelulushidupan larva udang vannamei hanya diinformasikan pada berbagai rentang salinitas, namun informasi sumber air untuk pemeliharaan larva belum banyak diungkapkan. Oleh karena itu, tujuan penelitian ini ialah untuk mengkaji kelulushidupan larva pada berbagai sumber air (air laut, air sumur dan air sungai).

\section{BAHAN DAN METODE}

\subsection{Waktu dan Tempat}

Penelitian ini dilakukan pada bulan April 2021 dan dilakukan selama 72 jam. Penelitian dilakukan di Laboratorium MIPA, Universitas Samawa, Sumbawa Besar, NTB.

\subsection{Alat dan Bahan}

Alat yang digunakan selama penelitian terdiri atas: toples plastik silindris bening berukuran $3 \mathrm{~L}$ sebanyak 12 buah, thermometer, refraktometer, counterbox dan gelas ukur. Bahan yang digunakan adalah air yang terdiri dari tiga sumber. Sumber air yang digunakan pada penelitian ini ialah air laut, air tawar (air sumur) dan air muara. Air laut (salinitas 19 ppt) diperoleh dari pantai Jempol yang berlokasi di Labuhan Sumbawa. Air sumur (salinitas 0 ppt) diperoleh dari sumur yang berlokasi di Kelurahan Sering, Sumbawa sedangkan air sungai diperoleh dari Sungai Brang Biji, Sumbawa. Selain air dari ketiga sumber tersebut, bahan lain yang digunakan dalam penelitian ini adalah larva udang vannamei post larva12. Larva udang ini diperoleh dari perusaan pembenihan yang ada di Sumbawa. Larva udang vannamei ini digunakan sebagai objek penelitian. Tissue digunakan sebagai bahan untuk membersihkan wadah.

\subsection{Prosedur Penelitian}

Penelitian ini merupakan penelitian eksperimen-deskriptif. Penelitian dimulai dengan merancang percobaan dan perlakuan, penentuan jumlah unit percobaan dan penempatan masing-masing unit percobaan. Penelitian ini menggunakan tiga perlakuan yaitu: 1) pemeliharaan larva pada air laut; 2) pemeliharaan larva pada air yang bersumber dari sumur dan 3) pemeliharaan larva pada air sungai. Masing-masing percobaan diulangi sebanyak tiga kali ulangan, sehingga ditetapkan 12 unit percobaan.

Sebelum wadah pemeliharaan digunakan, dilakukan pembersihan wadah dengan menggunakan sabun cuci, kemudian dicuci bersih dengan air tawar dan dikeringkan. Wadah kemudian diisi dengan air media (sesuai perlakuan) masing-masing 2 L. Setelah wadah dan media pemeliharaan siap digunakan, maka dimasukkan larva udang vannamei post larva-12. Sebelum diberi perlakuan, udang diaklimatisasi selama 15 menit. Setelah aklimatisasi, larva udang vannamei kemudian dimasukkan ke dalam media pemeliharaan. Pengamatan dilakukan terhadap kelulushidupan dan tingkah laku larva di dalam wadah pemeliharaan. Pengamatan kelulushidupan dilakukan setiap 12 jam sekali. Pengamatan ini dilakukan selama 72 jam.

\subsection{Teknik Pengumpulan Data}


Pengumpulan data dilakukan dengan mengamati jumlah kematian setiap 12 jam dan dilakukan selama 72 jam. Data kematian pada masing-masing unit percobaan kemudian dicatat dan dianalisis. Data kualitas air yang diukur pada penelitian ini adalah salinitas dan suhu. Pengukuran salinitas menggunakan refraktometer sedangkan pengukuran suhu menggunakan thermometer. Waktu pengukuran kedua parameter kualitas air tersebut mengikuti waktu pengamatan kelulushidupan larva. Pengukuran tingkat kelulushidupan dan tingkat kematian yaitu setiap 12 jam dan dilakukan selama 72 jam.

\subsection{Analisis Data}

Nilai kelangsungan hidup larva pasca pemeliharaan dirata-ratakan antar ulangan pada setiap perlakuan. Perbedaan signifikan kelangsungan hidup antar perlakuan diuji dengan menggunakan ANOVA satu arah. Semua analisis dilakukan dengan menggunakan perangkat lunak analisis statistik versi SPSS ${ }^{\circledR} 20.0$ untuk Windows ${ }^{\circledR}$

\section{HASIL DAN PEMBAHASAN}

Hasil pengamatan terhadap nilai salinitas masing-masing sumber air adalah 19 ppt untuk air yang diperoleh dari laut dan 0 ppt untuk salinitas air yang bersumber dari air sumur dan air sungai. Rendahnya nilai salinitas air dari laut diduga karena tingginya limpasan air hujan yang masuk ke dalam perairan. Sebagai informasi, pengambilan air dari ketiga sumber dilakukan pada musim hujan.

Hasil pengamatan terhadap tingkat kematian larva menunjukkan bahwa larva udang vannamei pada post-larva 12 mengalami kematian $100 \%$ pada perlakuan air tawar dan air payau. Kematian $100 \%$ di air tawar terjadi setelah 12 jam pemeliharaan. Larva yang dipelihara pada air payau mencapai kematian 100\% setelah 12 jam pemeliharaan. Berbeda dengan kedua sumber air tersebut, larva yang dipelihara pada air laut dengan salinitas 19 ppt menunjukkan kematian $0 \%$ hingga hari ke-tiga (jam ke 72) pemeliharaan atau dapat dinyatakan bahwa tingkat kelulushidupannya 100\% (Tabel 1).

Tabel 1. Tingkat kelangsungan hidup larva udang vannamei post-larva 12 yang dipelihara pada berbagai sumber air

\begin{tabular}{llllcccccc}
\hline No & Sumber & Nilai & \multicolumn{5}{c}{ Tingkat kelangsungan hidup berdasarkan jam pengamatan } \\
\cline { 5 - 9 } & air & salinitas & Awal & 12 jam & 24 jam & 36 jam & 48 jam & 60 jam & 72 jam \\
\hline 1 & Air laut & $0 \mathrm{ppt}$ & $100 \%$ & $100 \%$ & $100 \%$ & $100 \%$ & $100 \%$ & $100 \%$ & $100 \%$ \\
2 & Air sumur & $0 \mathrm{ppt}$ & $100 \%$ & $0 \%$ & $0 \%$ & $0 \%$ & $0 \%$ & $0 \%$ & $0 \%$ \\
3 & Air sungai & $19 \mathrm{ppt}$ & $100 \%$ & $0 \%$ & $0 \%$ & $0 \%$ & $0 \%$ & $0 \%$ & $0 \%$ \\
\hline
\end{tabular}

Pada waktu awal pemeliharaan, larva pada setiap perlakukan menunjukkan pergerakan yang aktif di kolom permukaan air. Larva yang dipelihara di air laut menunjukkan pergerakan yang aktif hingga pengamatan pada jam ke72. Berbeda dengan larva yang dipelihara di air laut, larva yang dipelihara di air tawar dan air muara menunjukkan peregerakan yang kurang aktif. Pergerakan larva terlihat seperti melakukan distribusi vertikal ke dasar perairan. Adanya pergerakan menuju dasar diduga disebabkan oleh hilangnya keseimbangan larva untuk berenang karena tekanan osmetik perairan. Larva kemudian mengalami kematian dan mengendap ke dasar perairan (Tabel 2)

Tabel 2. Tingkah laku larva udang vannamei post-larva 12 yang dipelihara pada berbagai sumber air

\begin{tabular}{|c|c|c|c|c|c|c|c|c|c|}
\hline \multirow{2}{*}{ No } & \multirow{2}{*}{$\begin{array}{l}\text { Sumber } \\
\text { air }\end{array}$} & \multirow{2}{*}{$\begin{array}{c}\text { Nilai } \\
\text { salinitas }\end{array}$} & \multicolumn{7}{|c|}{ Tingkah laku Larva pada setiap waktu pengamatan } \\
\hline & & & Awal & 12 jam & 24 jam & 36 jam & 48 jam & $60 \mathrm{jam}$ & 72 jam \\
\hline 1 & Air laut & $19 \mathrm{psu}$ & $\begin{array}{l}\text { Bergerak } \\
\text { aktif }\end{array}$ & $\begin{array}{l}\text { Bergerak } \\
\text { aktif }\end{array}$ & $\begin{array}{l}\text { Bergerak } \\
\text { aktif }\end{array}$ & $\begin{array}{l}\text { Bergerak } \\
\text { aktif }\end{array}$ & $\begin{array}{l}\text { Bergerak } \\
\text { aktif }\end{array}$ & $\begin{array}{l}\text { Bergerak } \\
\text { aktif }\end{array}$ & $\begin{array}{l}\text { Bergerak } \\
\text { aktif }\end{array}$ \\
\hline 2 & $\begin{array}{l}\text { Air } \\
\text { sumur }\end{array}$ & $0 \mathrm{psu}$ & $\begin{array}{l}\text { Bergerak } \\
\text { aktif }\end{array}$ & $\begin{array}{l}\text { Mengendap } \\
\text { ke dasar } \\
\text { wadah }\end{array}$ & & & & & \\
\hline 3 & $\begin{array}{l}\text { Air } \\
\text { sungai }\end{array}$ & $0 \mathrm{psu}$ & $\begin{array}{l}\text { Bergerak } \\
\text { aktif }\end{array}$ & $\begin{array}{l}\text { Bergerak, } \\
\text { namun } \\
\text { gerakan } \\
\text { lambat }\end{array}$ & $100 \%$ & $100 \%$ & & & \\
\hline
\end{tabular}

Berdasarkan Tabel 1, terlihat bahwa larva udang vannamei tidak mampu mentoleransi nilai salinitas 0 ppt hingga 12 jam. Udang vannamei post larva 12 yang dipelihara di air laut tidak menunjukkan adanya kematian (kelulushidupan 100\%). Hal ini menunjukkan bahwa kondisi air laut dengan nilai salinitas 19 ppt merupakan nilai salinitas yang masih mampu mendukung kelulushidupan larva. Hasil penelitian ini berbeda dari beberapa hasil penelitian sebelumnya. Garston (1986) melaporkan bahwa vannamei PL-12-14 mampu mentoleransi salinitas 0 ppt. Mair (1980) melaporkan bahwa Penaeus vannamei, mampu mentoleransi salinitas rendah (1-8 psu). Di Ecnador, P. vannamei post larva yang ditangkap di alam dilaporkan tumbuh di kolam dengan salinitas di bawah 2 ppt (Chauvin, 1983) dan dalam 0 ppt salinitas (Garston, 1986). Wulff (1987) melaporkan bahwa di Arizona, budidaya udang vannamei dilakukan di dalam air tawar total.

Rendahnya tingkat kelulushidupan larva yang dipelihara di air sumur dan air payau, diduga disebabkan ukuran larva yang masih sangat muda (PL-12). Beberapa hasil penelitian melaporkan bahwa larva udang vannamei PL-10 dapat mentoleransi nilai salinitas 4 ppt sedangkan PL yang lebih tua (PL-15 dan PL-20) dapat mentoleransi nilai salinitas 
hingga 1 ppt selama 48 jam pasca aklimatisasi. Hasil penelitian lainnya juga menunjukkan bahwa Penaeid PL tidak toleran terhadap fluktuasi salinitas yang besar ketika masih sangat muda. Umur toleransi terhadap fluktuasi salinitas yang luas pada sebagian besar paneid adalah antara PL-10 dan PL-40 (Mair, 1980; Cawthorne et al., 1983; Kumulu \& Jones, 1995; Rosas et al., 1999; Tsuzuki et al., 2000). Pada penelitian ini, larva PL 12 tidak mampu mentoleransi salinitas 0 ppt, hal ini membuktikan bahwa toleransi terhadap nilai salinitas juga diduga dipengaruhi oleh kualitas larva. L.vannamei yang dipelihara di air laut terbukti tumbuh lebih baik pada salinitas rendah (2-10 ppt) dibandingkan salinitas tinggi (> $15 \mathrm{ppt}$ ) (Bray et al., 1994; Samocha et al., 1998b). Hasil penelitian lain menunjukkan bahwa udang vannamei pada PL-15 dan PL20 lebih tahan terhadap perairan bersalinitas rendah dibandingkan PL-10. Fenomena ini telah dilaporkan pada spesies penaeid lainnya (Mair, 1980; Cawthorne et al., 1983; Kumulu \& Jones, 1995; Rosas et al., 1999; Tsuzuki et al., 2000) dan dalam L. vannamei oleh Olin \& Fast (1992) dan McGraw et al. (2002). Gao et al. (2016) melaporkan bahwa larva udang vannamei memiliki tingkat kelulushidupan $85.31 \pm 3.68$ pada salinitas 2 ppt dan $100 \%$ pada salinitas 20 ppt. Jika dibandingkan dengan hasil penelitian ini maka dapat dinyatakan terjadi perbedaan toleransi salinitas terendah yang dapat ditoleransi oleh udang vannamei. Nilai kelulus hidupan udang pada penelitian ini yang dipelihara pada salinitas 19 ppt memiliki nilai kelulushidupan yang sama dengan nilai kelulushidupan pada penelitian Gao et al. (2016) yaitu 100\%. Gao et al. (2016) juga menyatakan bahwa salinitas rendah sampai batas tertentu dapat menurunkan kinerja pertumbuhan dan tingkat kelangsungan hidup secara signifikan.

Hasil beberapa penelitian juga menunjukkan bahwa kelangsungan hidupa larva berbeda antar perairan dan wilayah. Toleransi terhadap salinitas pada PL juga tergantung pada strain udang (Harpaz \& Karplus, 1991; Kumulu \& Jones, 1995). Bray et al, (1994) menunjukkan bahwa strain Ekuador dari L. vannamei tumbuh lebih baik pada salinitas rendah daripada strain Meksiko. Faktor-faktor lain dalam air seperti konsentrasi $\mathrm{Na}^{+}$dan $\mathrm{Cl}, \mathrm{pH}$ dan kekerasan diketahui memengaruhi kelangsungan dan pertumbuhan udang, Kandungan $\mathrm{K}^{+}, \mathrm{Mg}^{2+}, \mathrm{Mn}^{2+}$ dan $\mathrm{SO}^{2-}$ juga memengaruhi kelangsungan hidup udang.

\section{SIMPULAN}

Udang vannamei pada fase post larva 12 tidak dapat hidup pada air yang bersumber dari air tawar dan air muara tanpa treatmen. Udang vanameii yang dipelihara pada air yang bersuumber dari laut memiliki tingkat kelangsungan hidup 100\%. Perlu dilakukan penelitian lanjutan terkait kualitas air (parameter fisika kimia lainnya) dari berbagai sumber air dan pengaruhnya terhadap keberlangsungan hidup larva udang vannameii.

\section{UCAPAN TERIMA KASIH}

Ucapan terima kasih disampaikan kepada pimpinan Fakultas Peternakan dan Perikanan, Universitas Samawa dan CV Top Benur yang telah memfasilitasi sebagian dari kebutuhan alat dan bahan penelitian.

\section{REFERENSI}

Castille, F.L., \& Lawrence, A.L. (1981). The effect of salinity on the osmotic, sodium andchloride concentrations in the hemolymph of euryhaline shrimp of the genusPenaeus. Comp. Biochem. Physiol. A 68: 75-80.

Cawthorne, D.F., Beard, T., Davenport, J., \& Wickins, J.F. (1983). Responses of juvenile Penaeus monodon Fabricius to natural and artificial sea waters of low salinity. Aquaculture. 32: 165-174

Gao W, Tian L, Huang T., Yao M., Hu W., \& Xu Q. (2016). Effect of salinity on the growth performance, osmolarity and metabolismrelated gene expression in white shrimp Litopenaeusvannamei. Aquaculture Reports. 4 : 125-129

Kumulu, M., \& Jones, D.A. (1995). Salinity tolerance of hatchery-reared postlarvae of Penaeus indicus H. Milne Edwards originating from India. Aquaculture. 130: 287-296

Laramore, S., Laramore, C.R., \& Scarpa, J. (2001). Effect of low salinity on growth andsurvival of postlarvae and Juvenile Litopenaeus vannamei. J. World Aquacult.Soc. 32(4): 385-392.

Li, E.C., Chen, L.Q., Zeng, C., Chen, X.M., Yu, N., Lai, Q.M., \& Qin, J.G. (2007). Growth,body composition, respiration and ambient ammonia nitrogen tolerance of thejuvenile white shrimp, Litopenaeus vannamei, at different salinities. Aquaculture. 265: 385-390.

Li, E.C., Chen, L.Q., Zeng, C., Yu, N., Xiong, Z.Q., Chen, X.F., \& Qin, J.G. (2008).Comparison of digestive and antioxidang enzymes activities, haemolymphoxyhemocyanin contents and hepatopancreas histological of white shrimp,Litopenaeus vannamei, at various salinities. Aquaculture. 274: 80-86.

Mair, J.McD. (1980). Salinity and water-type preferences of four species of postlarval shrimp (Penaeus) from west Mexico. J.Exp. Mar. Biol.Ecol. 45: 69-82.

McGraw, W.J., Davis, D.A., Teichert-Coddington, D., \& Rouse, D.B. (2002). Acclimation of Litopenaeus vannamei post larvae to low salinity: influence of age, salinity endpoint and rate of salinity reduction. J. World Aquac. Soc. 33(1): 78-84.

Ogle, J.T., Beaugez, K., \& Lotz, J.M.S. (1992). Effects of salinity on survival and growth ofpostlarval Penaeus vannamei. Source Gult Res. Rep. 8(4): 415-422.

Olin, P.G., \& Fast, A.W. (1992). Penaeid PL harvest, transport, acclimation and stocking. In: Fast, A.W., Lester, L.J. (Eds.), Marine Shrimp Culture: Principles and Practices. Elsevier, Amsterdam, pp. $301-320$.

Samocha, T.M., Lawrence, A.L., \& Poose, D. (1998). Growth and survival of juvenilePenaeus vannamei in low salinity water in a semiclosed recirculating system.Isr. J. Aquacult. Barnidgeh. 50(2): 55-59.

Silva, E., Calazans, N., Soares, M., Soares, R., \& Peixoto, S. (2010). Effect of salinity onsurvival growth, food consumption and haemolymph osmolality of the pinkshrimp Farfantepenaeus subtilis. Aquaculture. 306: 352-356. 
Saoud, I.P., Davis, A., \& Rouse, D.B. (2003). Suitability studies of inland well waters for Litopenaeus vannamei culture. Aquaculture. 217: $373-383$.

Rosas, C., Ocampo, L., Gaxiola, G., Sanchez, A., \& Soto, L.A. (1999). Effect of salinity on survival, growth, and oxygen consumption of postlarvae (PL10 - PL21) of Litopenaeus setiferus. J. Crustac. Biol. 19(2): 244-251.

Roy, L.A., Davis, D.A., Saoud, I.P., \& Henry, R.P. (2007). Branchial carbonic anhydraseactivity and ninhydrin positive substances in the Pacific white shrimp,Litopenaeus vannamei, acclimated to low and high salinities. Comp. Biochem.Physiol. A 147: 404-411.

Tsuzuki, M.Y., Cavalli, R.O., \& Bianchini, A. (2000). The effects of temperature, age, and acclimation to salinity on the survival of Farfantepenaeus paulensis postlarvae. J. World Aquac. Soc. 31(3): 459-468.

Zhou, J., Fang, W., Yang, X., Zhou, S., Hu, L., Li, X., Qi, X., Su, H., \& Xie, L. (2012). A nonluminescent and highly virulent Vibrio harveyi strain is associated with "bacterial white tail disease" of Litopenaeus vannamei shrimp. PLoS One. 7(2): e29961. https://doi.org/10.1371/journal.pone.0029961 